\title{
Cruise Ship: the Backbone of Future Tourism Industry in Indonesia
}

\author{
Tarsisius Catur Budi Nugraha \\ Sekolah Tinggi Pariwisata Ambarrukmo \\ Yogyakarta, Indonesia \\ mailcaturnugraha@gmail.com
}

\begin{abstract}
Indonesia considers the cruise ship industry as a potential source of economic growth. The paper discusses the cruise ship as the backbone of future tourism industry in Indonesia. The aim of the study is to provide some evidences of the discussion. The results of the study aim to help the stakeholders to realize the rising of cruise industry in East Asia and help the policy maker to develop infrastructures. The study is based on a literature review, data and analysis are based on a selection of information taken from different official worldwide reports, press releases, and previous studies. The results of the analysis show that the number of cruise ship call is still low and the fact that Indonesia accounts for only 5\% of total passenger and crew visit days throughout Southeast Asia become an issue. Furthermore the results show that the government should develop seaports that are supported by large airports and located in populous areas, these ports should be managed well to accommodate cruise ships, ferries, and roll-on/roll-off ships traffic. Based on the results of the study, it is recommended that further research is conducted to focus on kind of activities to attract the cruise traffic in Indonesia.
\end{abstract}

Keywords- cruise ship, cruise industry, future tourism, tourism industry, cruise ship tourism

\section{INTRODUCTION}

Cruise is a perfect getaway where people could enjoy both water and land tourist activities. Ward's (2015) study found the following: A cruise is an escape from the stresses and strains of life on land. It is a (mostly) pre-paid, hopefully hassle-free, and very importantly, crime-free vacation, where passengers only have to pack and unpack once. They seldom have to make blind choices, sleep in the same bed each night, and the ship moves the scenery for them (p. 22). The cruise vacations has evolved from a very small part of the oceanic passengers into a complete and complex vacation business, including all the different sectors of the travel industry (Brida \& Zapata, 2010) such as destination arrangement, port management, travel agent service, tourism provider, supply chain provider, and professional service provider. Globally, more than 22 million people took a cruise in 2014 , and all the new ships offered upto-date attractions and facilities aimed at expanding the market. By the end of 2014, more than 50 ships measuring over 100,000 gross tons were in service, with more than 20 new ships of various sizes had been scheduled for delivery between January 2016 and the end of 2019. In 2016, of the seven new ships scheduled for delivery the smallest in capacity is Viking Ocean Cruises' 47,000 ton with 928 passenger, while the largest is Royal Caribbean International's 225,000 ton with 5,400 passenger. Some new ships are clones of a similar series in terms of size, layout, and configuration, helping to keep costs down. With the exception of two AIDA Cruises ships being built by Mitsubishi Heavy Industries, Japan, for introduction in 2015 and 2016, all were being built by specialist shipyards in France, Finland, Germany, and Italy (Ward, 2015). The Cruise Lines International Association (CLIA) estimates there are 24.2 million peoples set sail in 2016.

The United States was the largest cruise market nation in the world with $51.7 \%$ of global 2014 passengers as reported by the CLIA. This is most likely due to Miami being the major hub for cruises headed to the Caribbean, which according to the same report, accounted for $37.3 \%$ of all 2014 cruise destinations. As the economy continues to grow and unemployment declines further, income level will rise. As a result, more people will be able to spend money on discretionary activities, including cruise travel. In addition, the aging U.S. population will further contribute to demand for cruises because the target market of cruise lines are individuals over 25 years of age with an annual income of at least $\$ 40,000$. Moreover, the CLIA estimates that $20.0 \%$ of the cruise market consists of retired individuals. As a result of the aging population and rising incomes, demand for cruises will increase substantially in the coming years (Soshkin, 2015). There was also a survey of best overall vacation conducted by CLIA as of February 2015, the result was $42 \%$ of respondent choose the crusie ship as the best tourist vacation, then $14 \%$ of land-based vacation, 9\% of all-inclusive resort and the rest is below $6 \%$

As ships development and passengers number grow, so do the expectation of Indonesian people to be the part of this industry. There is a few researches concerning the cruise traffic and its outlook. The lack of research and the fact that tourism infrastructure remains poorly developed are the main issues in the cruise industry. On the other hand, the policy maker will need these surveys and data to develop infrastructures. Building a cruise ship dock without knowing its real economic impact and how many ships will arrive is not wise despite there 
is a common belief that having cruise ships into the Indonesian port produces a major impact on the economy.

The aim of the study is to provide some evidences that cruise ships is the backbone of future tourism industry in Indonesia. The nature of the study is descriptive and the study is based on a literature, review, data and analysis are based on a selection of information taken from different official worldwide reports, press releases, textbooks, and previous studies. Therefore, the method of this study is documentary analysis on the secondary data. The next section of this paper presents an overview of the cruise industry with some data which permit us to analyse its growth, describe the market of cruises and discuss the performance of some cruise operators in the industry. In section 3 we describe the cruises industry in Indonesia. Section 4 is discussing some determinants that affect the capacity of port to attract cruise ships. Conclusions are in the last section.

\section{OVERVIEW OF THE CRUISE INDUSTRY}

\section{A. The Cruise Passenger}

Cruises have become one of the most dynamic and fastest expanding segments of the international tourist industry including the cruise passenger demand (Sun et al., 2011). Table 1 shows the global cruise passenger arrival and its annual growth rate for the period of 2009-2016

TABLE I. GLOBAL CRUISE PASSENGERS ARRIVALS, 2009-2016

\begin{tabular}{ccc}
\hline YEAR & $\begin{array}{c}\text { TOTAL } \\
\text { (MILLION) }\end{array}$ & $\begin{array}{c}\text { ANNUAL GROWTH } \\
\text { RATE (\%) }\end{array}$ \\
\hline 2009 & 17.8 & \\
2010 & 19.1 & $7.3 \%$ \\
2011 & 20.5 & 7.3 \\
2012 & 20.9 & $2.0 \%$ \\
2013 & 21.3 & $1.9 \%$ \\
2014 & 22.0 & $3.5 \%$ \\
$2015 \mathrm{P}$ & 23.2 & $5.3 \%$ \\
$2016 \mathrm{P}$ & 24.2 & $4.3 \%$ \\
\hline
\end{tabular}

In 2016, the outlook of the cruise industry continues to be strong with 24.2 million passengers and the growth is robust with the average annual growth rate of $4.5 \%$ for the periods of $2009-2016$.

The expansion of cruise capacity impacts the volume of visits across all destinations globally. Table 2 shows the world cruise line deployment and its change for the period of 20152016.

\section{TABLE II. GLOBAL CRUISE LINE DEVELOPMEN, BY REGION,} 2015-2016

\begin{tabular}{lllll}
\hline \multicolumn{1}{c}{ Region } & $\mathbf{2 0 1 5}\left(\%\right.$ ALBD $\left.^{*}\right)$ & $\mathbf{2 0 1 6}(\%$ ALBD & Change \\
\hline Caribbean & $36 \%$ & $34 \%$ & $-6 \%$ \\
Mediterranean & $20 \%$ & $19 \%$ & $-7 \%$ \\
Europe w/o Med & $11 \%$ & $14 \%$ & $25 \%$ \\
Aus./NZ/Pacific & $6 \%$ & $6 \%$ & $2 \%$ \\
Asia & $6 \%$ & $9 \%$ & $53 \%$ \\
Alaska & $5 \%$ & $4 \%$ & $-18 \%$ \\
South America & $3 \%$ & $3 \%$ & $-10 \%$ \\
All Other & $\mathbf{1 5 \%}$ & $\mathbf{1 4 \%}$ & $\mathbf{- 8 \%}$ \\
\hline
\end{tabular}

\footnotetext{
a. *ALBD (Available Lower Berth Day) is a standard measure of passenger capacity, it assumes double
} occupancy per cabin for sale
The cruise industry in Asia grows 53\% yearly in 2016, and currently on the biggest 4 global cruise line deployment with $9.2 \%$ of total capacity (ALBD). The next table presents the deployment of cruise line in Asia and its change for the period of $2015-2016$.

TABLE III. CRUISE LINE DEPELOPMENT IN ASIA, BY REGION, 2015-2016

\begin{tabular}{cccccccc}
\hline \multirow{2}{*}{ Region } & \multicolumn{2}{c}{ Ports } & \multicolumn{2}{c}{ Call } & \multicolumn{3}{c}{ Psg. Destination Days } \\
\cline { 2 - 7 } & 2015 & 2016 & 2015 & 2016 & 2015 & 2016 & Chang \\
\hline $\begin{array}{c}\text { East } \\
\text { Asia }\end{array}$ & 95 & 116 & 1,69 & 3,54 & 3,89 & 7,75 & $99 \%$ \\
$\begin{array}{c}\text { South } \\
\text { east }\end{array}$ & 61 & 75 & 1,97 & 1,83 & 2,88 & 2,95 & $3 \%$ \\
$\begin{array}{c}\text { South } \\
\text { Asia }\end{array}$ & 12 & 13 & 238 & 195 & 225 & 154 & $-32 \%$ \\
Total & 168 & 204 & 3,90 & 5,57 & 7,00 & 10,87 & $55 \%$ \\
\hline
\end{tabular}

There is a dramatic shift deployment in East Asia with $99 \%$ change year on year in 2016, in the same period they host $63.5 \%$ of calls to see $71.3 \%$ of Asia's passenger destination days. Some countries in Asia that hosting greatest volume of calls are presented in the next table:

Japan, China, South Korea, Vietnam and Malaysia host the greatest volume of calls that receive over 400 calls in 2016, while Indonesia is still in the $10^{\text {th }}$ rank with 172 calls. The China's growth is in the fastest pace with $183 \%$ increase year on year.

\section{B. The Cruise Operators Performance}

The major players in the cruise ship industry as of November 2015 are Carnival Corporation (Carnival) with $18.9 \%$ market share, Royal Caribbean Cruises Ltd. with $11.8 \%$, Norwegian Cruise Line Holdings Ltd. with $8.0 \%$, and other with $61.3 \%$. The market share info could be different from report to other report since there were many merger and acquisition.

TABLE IV. CRUISES DESTINATION BY TOTAL CALLS IN ASIA, 2015-2016

In 2016, the outlook of the cruise industry

\begin{tabular}{lccc}
\multicolumn{1}{c}{ Countries } & $\mathbf{2 0 1 5}$ & $\mathbf{2 0 1 6}$ & Change \\
\hline Japan & 646 & 1.526 & $136 \%$ \\
Malaysia & 580 & 422 & $-27 \%$ \\
South Korea & 377 & 745 & $98 \%$ \\
Singapore & 374 & 391 & $5 \%$ \\
Thailand & 374 & 291 & $-22 \%$ \\
Vietnam & 316 & 466 & $47 \%$ \\
China & 300 & 850 & $183 \%$ \\
Hong Kong & 200 & 185 & $-8 \%$ \\
Indonesia & 196 & 172 & $-12 \%$ \\
Taiwan & 175 & 234 & $34 \%$ \\
\hline
\end{tabular}


Below is a brief report from Soshkin (2015) of some major cruise operators:

\section{1) Carnival Corporation}

Carnival is a global cruise company with a portfolio of 13 of the leading cruise operators in North America, Europe, Australia and Asia, aking it the largest cruise operator in the world. With headquarters in Miami and London, Carnival operates 100 ships with a capacity for over 210,000 passengers, which is an estimated $43.6 \%$ of global capacity. In 2014 , the company generated $\$ 15.9$ billion in revenue and employed 12,900 part- and full-time onshore employees and 81,200 crewmembers. Carnival currently operates four brands within North America: Carnival Cruise Lines, Princess Cruises, Holland America Line and Seabourn. Together, these brands account for $60.2 \%$ of the company's overall revenue.

\section{2) Royal Caribbean Cruises Ltd.}

Royal Caribbean's passenger capacity of almost 106,000 makes it the second-largest cruise company in the world. The company is headquartered in Miami, was founded in 1968 in Norway, and currently owns five brands: Royal Caribbean International, Celebrity cruises, Pullmantur, Azamara Cruises and Croisieres de France (CDF). Currently, the company's 43 ships travel to about 480 destinations worldwide, including Alaska, Asia, Bermuda, Europe, Latin America, the Middle East and New Zealand. In 2014, the company brought in about $\$ 8.1$ billion in revenue and employed over 64,000 people.

\section{3) Norwegian Cruise Line Holdings Ltd}

Norwegian Cruise Lines (NCL) is the world's thirdlargest cruise line. It was founded in 1966 by Knut Kloster and Ted Arison (who then went on to found Carnival). With roughly 24,900 employees and 21 ships worldwide, NCL has operations that span across the globe, as they docked over 100 ports worldwide in 2014. In the same year, the company generated \$3.1 billion in worldwide revenue. With the U.S. market being dominated by Royal Caribbean and Carnival, Norwegian has primarily focused its efforts in Europe. This is shown in them being named "Europe's Leading Cruise Line" five years in a row by the World Travel Awards.

While the major cruise operator's revenue steadily grew over the past five years, growth was slowed by relatively weak demand and a number of accidents. The cruise vacations are typically less expensive than other types of long distance trips, with passengers tending to be families and older individuals that were less impacted by the recession, allow this segment's revenue to consistently increase. However, the reputation of cruise lines was damaged by the sinking of the Costa Concordia in 2012 and a fire on a similar vessel that left more than thousand people on board with no power in the Indian Ocean. The cruise industry is in the mature phase since there is close correlation between overall economic activity and the industry revenue, in other word, when the economy is doing good so is the industry and vice- versa. The industry has also gone through some consolidation, indicated by the fact that the cruise operators increase utilization and efficiency, as well as reduce competition and deal with overcapacity (Soshkin, 2015).

\section{Cruises Industry in Indonesia}

1) Comparative \& Competitive Strength

Indonesia's location and climate are interesting, it consists of five large islands and 13,677 smaller islands (about 6,000 of which are inhabited) forming an arc between Asia and Australia. With a total area of $1,919,440 \mathrm{sq} \mathrm{km}(741,100 \mathrm{sq}$ mi). It extends $5,271 \mathrm{~km}(3,275 \mathrm{mi})$ east-west and 2,210 km $(1,373 \mathrm{mi})$ north-south. The five principal islands are Sumatra; Java; Borneo, of which the $72 \%$ belonging to Indonesia is known as Kalimantan; Sulawesi, formerly called Celebes; and Irian Jaya (West Irian), the western portion of the island of New Guinea. Indonesia has land boundaries with Malaysia (on Borneo), Papua New Guinea (on New Guinea), and East Timor (on Timor). It is bounded on the north by the South China Sea, on the northeast by the Pacific Ocean, and on the southwest by the Indian Ocean. Indonesia's total land boundary length is $2,830 \mathrm{~km}(1,758 \mathrm{mi})$. Its coastline is 54,716 $\mathrm{km}(33,999 \mathrm{mi})$. Straddling the equator, Indonesia has a tropical climate characterized by heavy rainfall, high humidity, high temperature, and low winds. Average humidity is $82 \%$. Altitude rather than season affects the temperature in Indonesia. At sea level, the mean annual temperature is about $25-27^{\circ} \mathrm{C}\left(77-81^{\circ} \mathrm{f}\right)$. There is slight daily variation in temperature, with the greatest variation at inland points and at higher levels (Encyclopedia.com). In general, tourists want to feel a different temperature and climate while hoping that the difference is still friendly to their human body adaptation, since the characteristic of tourism is tasting something different.

Furthermore, according to ILO (2012), the strength of Indonesia includes:

\section{2) Socio-cultural}

Indonesia's tourism is benefiting from the cultural assets, heritages as well as living cultures with their local wisdom and unique traditions. Enthusiastic spirits to conserve local cultures are strengthening. An increase in pride in culture, revitalization of culture, improved conservation and restoration of cultural heritage sites is proven, among others by the Ministry of Public Works with its Heritage City Planning Program.

\section{3) Environment}

Local wisdom in some localities has proven to be effective in the protection of natural resources. Awareness of the importance of an environmentally friendly development is increasing. Environmental groups and activists for green development and green attitudes emerge in leading provinces like Bali, Jakarta, West Java and others. At the destinations' local level, the country shows many cases of best practices on ecotourism.

\section{4) Bio- and cultural diversity}

This area has long been Indonesia's strength as a basis for tourism development. Natural phenomena and features like: volcanoes and their calderas, mountains, lakes, caves, tropical rain forests, savannahs, rivers, beaches, underwater life and cultural events, festivals, craft as well as heritages are Indonesia's tourism resources that are still waiting for responsible and creative packaging. 


\section{5) Destination Planning}

Most regions have been aware of the need and importance of planning for tourism development. At the national level the National Tourism Master Plan has been legitimized. Leading tourism destinations like Bali and Jakarta have already integrated their tourism development plan into their comprehensive spatial master plans.

\section{6) Political support}

Indonesia's tourism is supported by an enhanced political will, among others indicated by the issuance of the Presidential Instruction No.16 - 2005 and an increased national budget for the Ministry of Tourism and Creative Economy. Currently the government announced that Indonesia's core business is tourism, based on this statement, it can be concluded that eventually there will be a significant portion of budget that would be spent in tourism sector.

According to CLIA (2014), the principal cruise destinations in Indonesia were Bali, Komodo, Semarang, Lombok and Jakarta. All ports in Indonesia featured primarily as transit destinations. Indonesia accounted for about $5 \%$ of total passenger and crew visit days $(180,116)$ throughout Southeast Asia with transit passenger visit days accounting for $78 \%$ of the total. Transit passengers spent an average of US\$147 (Rp1.89 million) per visit day with expenditures for shore excursions and retail shopping accounting for about $67 \%$ of the total. Direct expenditures by the cruise lines and their passengers and crew totaled US\$36.9 million (Rp475 trillion) with passengers accounting for $79 \%$ of the total, and cruise lines for $16 \%$. The direct expenditures generated US\$77.8 million (Rp1,003 trillion) in output and 948 full- and part-time jobs paying US $\$ 16.3$ million (Rp210 trillion) in employee compensation. Overall, the economic impacts in Indonesia accounted for about $3 \%$ of output and employment impacts throughout Southeast Asia. The cruise industry directly employed 15,532 residents of Indonesia. Virtually all of these employees work as crew onboard cruise ships. Including these cruise line employees, the total employment impact increases to 16,480 jobs paying US\$146 million (Rp1,889 trillion) in compensation in Indonesia.

Even though Indonesia has all the comparative and competitive strength to be the part of the cruise industry, the number of call is still low and the fact that Indonesia accounted for only about $5 \%$ of total passenger and crew visit days $(180,116)$ throughout Southeast Asia become a major issue. The maritime ideology is then introduced to explain this issue, despite the acceptance of this ideology is still slow, it is on going.

\section{- Maritime Nation}

Indonesia should has a strong maritime industry with many ships traffic in its ocean. Ships those serve deep sea, shore, lake, and river every day, so the Indonesian peoples won't be separated by the sea, because the sea is actually a unification instead of a separation. This is an affirmation of Indonesia as a maritime nation. Furthermore, the government already initiate the toll sea program as the realization of Nawacita. Indonesia with Nawacita consider the cruise ship industry as a potential source of economic growth, that also strengthen the Indonesian identity in maritime ideology. Indonesia has begun adding new ports of call to existing and new itineraries in the toll sea program, and providing a better accessibility to the embarkation ports in the infrastructure development program. These developments has been giving hopes to all tourism industry players.

Cruise ship is an interesting investment opportunity that is benefited from the development of maritime industry. The cruise ship industry is expected to grow and become the backbone of future tourism since ships could serve deep sea, shore, lake, and river as found in Indonesian archipelago. Along with its assets and government support in infrastructure and security, a pleasant journey on Indonesia's sea should be realized. Tourism sector is a strategic industry that should be developed along with ports and other infrastructure developments program. Hopefully, the toll sea program is running well with many ships traffic from Sabang to Merauke. When this happen, sooner or later the cruise ship will be the favorite tourist activity in Indonesia.

Aside of maritime ideology, there is a research that trying to explain some determinants to attract international cruise line into certain ports of call and will be discussed in the next section.

\section{Determinants of Cruise Traffic}

When a cruise ship entering a port, many tourists will go to the land, they will buy local produk or service, these will create multiplier effect and become the source of economic growth and estimated in GDP. Before this happen one should think how to attract them. Manzano et all (2014) study the determinants that affect the capacity of ports to attract cruise ships in Spain. The conclusion is that the likelihood of having cruise traffic is linked to ports located in populous areas and close to large airports, ports not specialized in container traffic but sharing facilities with ferries traffic and ports having a minimum depth of water. The amount of cruise traffic that a port can generate is also related to the population and the air connections, along with the tourist appeal and the facilities shared with other types of port traffic, namely roll-on roll-off (ro-ro) and ferries. Apart from the size and population of a city, the findings show that it should be attractive for tourists and islands that possess a certain mystique for this type of tourism. Cruise traffic is a complex tourism product and its management is equally complex. Cruise traffic management is complicated as the researcher is not only found evidence of signs of conflict with container traffic, but also synergies with ferries and ro-ro traffic. Indeed, cruise traffic alone does not allow the profitable infrastructure to be constructed that shipping firms need. However, cruise traffic may not be compatible with the traffic of reference at many ports, which is container traffic.

\section{CONCLUSIONS}

As the industry is in the mature phase and consolidated, more operator reduce the competition by opening niche market like moving to Asia. In 2016, the cruise industry in Asia grows $53 \%$ year on year, and now on the biggest 4 global cruise line deployment with $9.2 \%$ of its capacity (ALBD). A couple destination that officially highlighted by CLIA in 2016 is 
Japan Cruise and Cambodian Cruise. A Japan cruise offer the opportunity to marvel at the 410 year old Nijo Castle in Kyoto, board the famous bullet train to Tokyo, and take a scenic drive along Mount Fiji. In Cambodia cruise, passengers can take Ama Waterways' Vietnam, Cambodia \& the Riches of the Mekong cruise.

Most area in Indonesia has friendly temperature, humidity, and wind to foreigner. Tourist usually want to feel different climate, since the characteristic of tourist is tasting something different. However, to attract more cruise traffic into Indonesian sea, that is not enough, as studied by Manzano et all (2014) the government should develop seaports that supported by large airports and located in populous areas, this ports should be managed well to accommodate cruise ship, ferries, and ro-ro traffic. This study could be applied in Indonesia, since it has the same strength and opportunities to Spain; LCC flight that supporting travelling, Spain is part of the Mediterranean cruise while Indonesia is part of the exotic cruise including

Singapore, Malaysia, Thailand, Cambodia, Korea, and Japan, and islands those possess mystique attraction.

Considering the rising of cruise industry in East Asia, Indonesia should be alarmed, wake up and start to work hard developing infrastructure as well as promoting all the assets. The number of call is still low and the fact that Indonesia accounted only for about $5 \%$ of total passenger and crew visit days throughout Southeast Asia become a major issue. Now, cruise industry is gaining momentum, since the government just announce that the tourism is the core business and the country branding of Wonderful Indonesia is having a good ranking internationally. The cruise industry is also supported by Nawacita declared by the President of Republic Indonesia Mr. Joko Widodo. With some

Comparative and competitive strengths, Indonesia should gain some benefit from the momentum as soon as possible. Promotion and building more port of calls, port that built not only for freight ship but a clean port with hospitality that mirroring the local culture. Indonesia has begun adding new ports of call to existing and new itineraries in the toll sea program, and providing a better accessibility to the embarkation ports in the infrastructure development program. These developments has been giving hopes to all tourism industry players, however compare to Malaysia the numbers of ports of calls is still very low. With all assets and competitive strengths, the cruise ship in Indonesia should be the backbone of future tourism and the answer of what is it take to attract more tourist and win the competition.

Further research need to be conducted in order to focus on kind of activities to attract the cruise traffic in Indonesia.

\section{REFERENCES}

Brida, J.G. and Zapata, S. (2010). Cruise tourism: economic, socio-cultural and environmental impacts. Int. J. Leisure and Tourism Marketing, Vol. 1, No. 3, 205-226.

Indonesia. (n.d.). In Worldmark Encyclopedia of Nations. Retrieved

from http://www.encyclopedia.com/places/asia/indon esianpolitical-geography/indonesia

International Labour Organization (ILO). (2012). Strategic Plan Sustainable Tourism and Green Jobs for Indonesia Ministry of Tourism and Creative Economy of the Republic of Indonesia in cooperation with the International Labour Organization. Retrieved from https://www.cbd.int/financial/greenmarkets/ind onesiagreentourism-ilo.pdf

Manzano, J.I.G., Fageda, X., and Laxe, F.G. (2014) An analysis of the determinants of cruise traffic: An empirical application to the Spanish port system Transportation Research, Part E 66, 115-125.

Soshkin, M., (2015) Ocean \& Coastal Transportation in the US, IBISWorld, U.S.

Sun, Jiao, Y., Tian, P. (2011). Marketing research and revenue optimization for the cruise industry: a concise review. Int. J. Hospitality Manage. 30, 746-755.

The Cruise Lines International Association. (2016). 2016 Cruise Industry Outlook. Retrieved from http://cruising.org/about-the- industry/research/2016state-of-the-industry

The Cruise Lines International Association. (2016). Asia Cruise Trends 2016. Retrieved from http://cruising.org/about-the- industry/research/asiacruise-trends-2016

The Cruise Lines International Association. (2015). 2015 Cruise Industry Outlook; Cruising to New Horizons and Offering Travelers More, Retrieved from http://cruising.org/about-the- industry/research/2015state-of-the-industry

The Cruise Lines International Association. (2015). 2015 Annual Report. One Voice:Advancing Our Industry Together. Retrieved from http://cruising.org/about-theindustry/research/2015-annual-report

The Cruise Lines International Association. (2014). Economic Contribution of Cruise Tourism in Southeast Asia - 2014 Major Finding. Retrieved from http://cruising.org/docs/default- source/marketresearch/2014-southeast-asia- economic-impact-studynbsp---major- findings.pdf?sfvrsn $=0$

Ward, D., (2015) Berlitz Cruising \& Cruise Ships (23rd ed.), Apa Publications Ltd., UK. 